\title{
Construction of Credit Mechanism in E-commerce SocietySubtitle as needed
}

\author{
Chenyu Liu, Miaoyan Shen, Bin Huang \\ School of Media Studies \& Humanities, Zhejiang University City College, Hangzhou, China \\ Email:1065557066@qq.com
}

\begin{abstract}
Today, E-commerce has evolved into an indispensible part in people's life and work, due to its features of convenience, high-efficiency, etc.As E-commerce becomes popular and develops sharply, its credit crisis emerges increasingly remarkably, including the inadequate regulation, the network complaints, and the rising number of fraud cases. Because of network vulnerabilities and illicit competition in trading market, consumers have substantially reduced their trust in E-commerce. It is apparent that E-commerce credit crisis has turned into one of the main obstacles impacting the development of E-commerce.
\end{abstract}

Key words-E-commerce, credit crisis, construction system, optimization, renovation

* Chenyu liu is the first author; Miaoyan Shen is the correspondence author; Bin Huang is the instructor.

\section{CRedit Crisis Status Of E-COMMERCE}

According to 2011-2012 iResearch China E-Commerce Research, in 2011, China's E-commerce market achieved trading volume of 6,300 billion Yuan, with annual growth of $32.4 \%$, constituting $13.4 \%$ of GDP--4,720 billion Yuan. In 2011, the trading volume of online shopping market reached 766.6 billion Yuan. By the end of December 2011, the trading volume of network market had broken 800.0 billion Yuan, with year-on-year growth of 57\%[Data from IResearch]. According to the 30th Statistics and Investigation on the Development of China Internet Network made by CNNIC, the user quantity of online payment has exceeded 187,220,000 during December 2011 and June 2012, as Figure1 shows[ CNNIC Data from CNNIC].

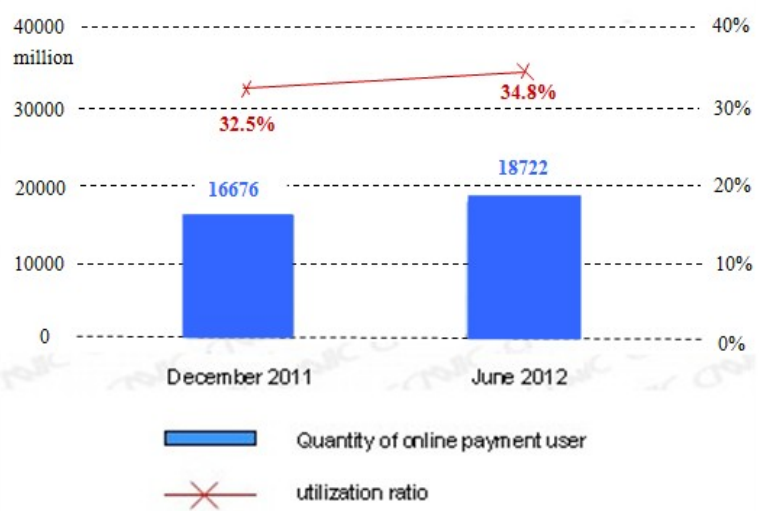

Source:Statistics and Investigation on the Development of China Internet Network

Figure 1. Quantity of online payment user during December 2011June 2012
However, E-commerce also exposes a string of problems about network technology, credit mechanism, E-commerce trade security and so on, when developing rapidly.

\section{A. Low satisfaction}

In the survey on nationwide social livelihoods, the negative comments given to the credit trading environment in online shopping and E-commerce industry only rank second to that of medical industry, as credit mechanism has serious vulnerabilities. According to monitoring data presented by the Public Service Platform of Complaints and Right Protection of China E-Commerce, in the first half of 2012, online shopping has received complaints that took up $56.5 \%$ of E-commerce complaints in a largest proportion, followed by online group shopping, accounting for $20.1 \%$, then by E-business, representing $6.7 \%$, and fourthly by B2B online trade, constituting 3.6\%. (Ref. Figure2 and 3)

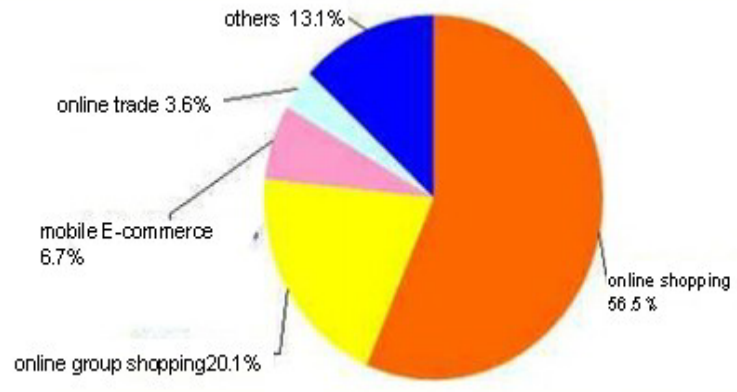

Source:China E-commerce Research Center

Figure 2. Distribution of the complaining fields of E-commerce in the first half of 2012

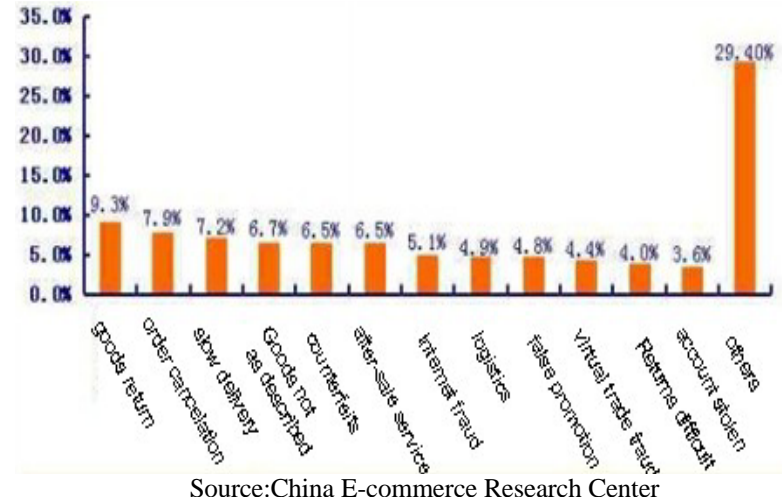

Figure 3. The distribution of hot complaining problems of online shopping in the first half of 2012 


\section{B. Internet fraud}

Relative data statistics show that consumers have reduced their trust in internet trading market. Meanwhile, corruption exists in international business environment. Published on April 20, 2012, IT Times exposes that the staffs of a certain well-known online shopping website are corrupt. The article points out that the staffs seek personal gains with power, through the methods from hidden means such as illegal credit upgrade and negative comment deletion, to power rent-seeking for the third party of Taobao via agency, and then to company's equity participation after the launch of Juhuasuan (Group bargain). The staffs spread diversified corruption forms over the whole online shopping system to gain illegal profits in a flagrant way. The corruption develops from personal bribe-taking to current trans-departmental and trans-occupational group corruption that involves Taobao's technical personnel, activity planning personnel, and customer service personnel.

\section{System Vulnerabilities}

The development of E-commerce network technology fails to keep up with the prompt development of Ecommerce market, while the huge amount of market circulation requires the support of the powerful E-commerce network technology. Data statistics show that with the rapid development of E-commerce market, cyber-attack case has been increasing. Besides, E-commerce market is exposed to some severe safety threats including hacker attack, wiretap, masquerade, computer virus, information leakage, loss, alteration and destruction, software vulnerabilities, etc.

\section{The Basic Features Of E-Commerace Credit CRISIS}

E-commerce develops speedily in China due to its features of convenience, high-efficiency, no geographical restriction, etc. Not only does the rising of E-commerce promote the economical development and change the modes of economic development, but it brings new crises and challenges for the market.

\section{A. Constraints of social environment}

\section{1) Unsound social system}

The emergence of E-commerce credit crisis is bound up with the context of socialist economic development in China. Now, China's market economy, which still stays at the development stage, only sets up an unsound social system. As a consequence, a great number of unscrupulous behaviors exist in the society including fraud, breach of contract, counterfeits production, tax evasion, etc.

\section{2) Poor self-disciplined consciousness}

People still have inadequate understanding on the development criteria of market economy, showing poor consciousness of independently observing the development criteria of market economy. In addition, the two parties of Ecommerce trade reside in different places. The merchants will therefore make counterfeits more unscrupulously.

\section{B. Unsound legal system}

Study on E-commerce Law relatively lags behind. China shows obvious deficiencies in legislation and lawenforcement in respect of E-commerce credit trade. Notwithstanding the E-commerce Laws and Regulations released by the Government, the two trading parties show large difference in cognition of laws and regulations; meanwhile, the laws and regulations put constraints on merchant's benefits, which goes against their interests.

There still are many obstacles restricting the Ecommerce development, such as divided policies from various sources, blurry boundary, multiple management, more normalized control but less promotion, many security risks for trading payment, no protection for intellectual property, difficult financing, etc.

\section{Vulnerabilities of government regulation}

E-commerce shows the features of virtuality, globalization, etc. In the face of virtual network and broad space of network activities, traditional administration system for industry and commerce is exposed to serious impact and challenges. Despite clear division of work and regulatory objective in each regulatory authority, the blurry and crossing boundary of labor division results in regulatory personnel's unclear understanding on their jurisdictional scope and work. Notwithstanding diversified network commodities, the regulatory scope doesn't expand with the change of commodities. Except business entity and network advertisements, the regulation over the problems such as illegal transaction of virtual coins and articles still needs to be strengthened.

\section{Illicit competition in market operation environment}

Some net friends indicate that they were deceived in the activity of double 11 in T-mall which ended only a few days ago. They mention that the merchants raised the prices of commodities under the table before the eve of the activity, and then allowed a discount of $50 \%$ on the day of activity. Apart from this unjustifiable means of competition, Ecommerce trade also comprises other means, such as infringing business secret, publishing false information, lacking credit service guarantee, belittling rivals' commodities.Based on the investigation report of Ecommerce Trust Evaluation Center of Electronic Commerce Association, $71.1 \%$ of respondents have ever questioned the authenticity and legality of some websites; $56.4 \%$ have ever came across the problems of false online shopping information; 40.9\% have ever encountered the conditions that the promises of online service are false or not fulfilled[From Investigation Report of E-commerce Trust Evaluation Center of Electronic Commerce Association]

\section{CONSTRUCTION OF E-COMMERCE CREDIT SySTEM}

\section{A. Construction of sound social credit system}

\section{1) Law system}

In order to solve the credit crisis problem of E-commerce trade, it is most urgent to optimize the E-commerce laws and do the best to define all clauses of laws, so as to make both 
trading parties understand their responsibilities, obligations and rights. E-commerce covers wide range and many activity contents. So it is necessary to conduct scientific and detailed management. Besides, E-commerce law provisions shall explicitly define the direction and target of E-commerce development.

China has advantages in aspect of legislation cost. Ecommerce legislation of western Countries lag behind relatively as result of high legislation cost, while China has a better chance to advocate and optimize corresponding laws and regulations, so that it plays a dominant role in global ecommerce.

\section{2) Moral system}

It is necessary to establish social credit assessment institutions to conduct credit investigation and credit assessment on trading market. According to the statistics of Public Service Platform of E-commerce Complaints and rights Protection, about 100,000 E-commerce complaint cases were received last year. Consumers showed low satisfaction with enterprises' response to complaints, including online shopping and group buying enterprises. On the one hand, credit system can reduce the trading risks and avoid economic losses. On the other hand, it can allow the operators to understand their shortages by self-discipline, so as to establish good business image. Therefore, the credit crisis will substantially decrease.

\section{3) Government regulation}

The Eleventh Five-Year Plan for E-commerce Development suggests establishing coordination mechanism in aspects of policy formulation and major projects approval between related departments, so as to develop a joint force and strengthen government's macro guidance for Ecommerce development. Chinese government adopts the model of "government-led and market-driven combination" to regulate E-commerce. Government is supposed to establish E-government, namely, a virtual government set up on the internet based on establishment of government website, from which people can get policy information and service. Besides, government can control and monitor Ecommerce activities on the internet as well. With Egovernment, government can conduct more efficient regulations over e-commerce. Once government can conduct efficient regulation over E-commerce market, the credit crisis in trading market will be certainly controlled in an effective way.

\section{B. Consumer's right protection consciousness}

The sixth clause of Law of the People's Republic of China on the Protection of Consumer Rights and Interests explicitly stipulates that it is the common responsibility of the whole society to protect legitimate rights and interests of consumers. The State encourages and supports all organizations and individuals to implement social regulation over the behaviors of damaging consumer's legitimate rights and interests. Consumers are expected to strengthen right protection consciousness and protect their legal rights and interests. In E-commerce trading, consumers are supposed to safeguard their rights specific to the part which sellers do not achieve according to trading criterion.

\section{Renovation of network technology}

\section{1) Construction of security system}

E-commerce system security is consisted of three parts physical security, information security and operation security. Aimed at three parts, it is necessary to carry out technological innovations to maintain the security of trading environment and guarantee smooth trading. Meanwhile, it is also required to enhance network defense technologies, such as, network security monitoring devices, access equipment, firewall, browser software, certificate, commercial software, security toolkits software, transmission line security protection, anti-intrusion measures, data encryption, access control, and authentication mechanism.as to establish good business image. Therefore, the credit crisis will substantially decrease.

\section{2) Reinforcement of system maintenance}

Network devices normally have corresponding monitoring software, which can automatically recognize, display and manage network topology, configure and manage network system node as well as diagnose, display and notify system failures. Besides, in case of any failure, it can be fixed immediately.

\section{CONCLUSION}

In the booming era of E-commerce, credit crisis is a stumbling block for E-commerce; thus, it is necessary to optimize laws and regulations, establish sound social credit mechanism and regulate trading behaviors in E-commerce market. Construction of trading credit system is of great significance for China's economic development. A sound credit mechanism does not come into existence overnight; instead, it is a huge and complicated project. Only by creating credible internet environment, can the development potential of E-commerce market be unlocked, and meanwhile, only by establishing a credible trading platform, can the E-commerce develop stably and healthily.

\section{REFERENCES}

[1] Mingke He, A Lamusi, Li Anyu, Comparative Stud on Sino-German Commodity Transaction Regulation [M]Beijing, China Industry and Commerce Associated Press 2011. PP280-296

[2] Xiaojun Tong, Ecommerce Security and Cases, [M]Beijing, China Railway Publishing House, 2010 .PP35-44

[3] Cequn Lou, Weijun Wang, Lei Cheng, E-commerce Policies and Regulations [M]Wuhan, Huazhou Normal University Press, 2008.PP28-39 